\title{
An investigation on the frequency of thoughts, readiness and suicide attempt in individuals with thalassemia
}

\author{
SAHAR ATTAR ${ }^{1 *}$, NOUR MOHAMMAD BAKHSHANI ${ }^{2}$, QASEM MIRI ALIABAD ${ }^{3}$ \\ ${ }_{1}^{1}$ MSc Student in Clinical Psychology, Zahedan University of Medical Sciences, Zahedan, Iran. \\ 2 Professor of Clinical Psychology, chidren and adolescent health research center, Zahedan university of medical sciences, Zahedan, Iran. \\ ${ }^{3}$ Associate professor of pediatric hematology-oncology, chidren and adolescent health research center, Zahedan university of medical \\ sciences, Zahedan, Iran. \\ *sahar.mgp74@gmail.com
}

\begin{abstract}
Background and Aim: Thalassemia major is one of the most common chronic genetic diseases in the world and in Iran that can impose many adverse effects on the self and society. Psychologically, patients with thalassemia are under stress. According to the World Health Organization (WHO), suicide is one of the leading causes of death worldwide. It is important to identify the people who have the highest risk factors for suicide. The present research investigates the frequency of thoughts, readiness and suicide attempts in people with thalassemia.

Methods: This was a cross-sectional study. Its sample was 150 patients with thalassemia in the age range of 10 to 46 years whom we selected through census by sampling at convenience. We gave to patients a standardized Beck Suicide Thought Assessment Questionnaire. We analyzed the research data using descriptive and inferential statistical tests.

Results: From among 150 patients with thalassemia in this study, 57.3\% of the respondents were male and $42.7 \%$ were female. The results showed that there was a negative and significant relationship between suicide thoughts and attempts and age $(-0.234)(P<0.05)$. The mean prevalence of suicide in men $(1.89)$ was significantly higher compared to women $(0.79)(P<0.05)$. We did not observe significant difference in prevalence of suicide thoughts and attempts between married and single groups with a mean difference $(0.69)(P<0.05)$ and, in different educational groups, no significant difference was reported $(P>0.05)$.

Conclusion: The findings of this research showed that among patients with thalassemia, the prevalence of suicidal ideation has a significant percentage. Since suicidal ideation provides a platform for preparation and attempt to commit suicide, so by providing mental health services and regular screening, we can take an effective step to prevent this problem among patients with thalassemia.
\end{abstract}

Keywords: Thalassemia, Suicidal ideation, Suicide.

\section{INTRODUCTION}

Thalassemia is one of the most common genetic disorders in the world, first diagnosed by Lee and Gypsy in 1952 (1). The term thalassemia (2) is derived from the Greek words Thalassa (sea) and heama (blood) (3). Because this situation was first observed in populations living in the Mediterranean $(4,5)$. Its characteristic is a decrease in the synthesis of one of the two types of polypeptide chains $(\alpha)$ or $(\beta)$ that form normal adult hemoglobin ( $\mathrm{HbA}, \alpha 2 \beta 2)(6)$. Depending on the genes that affect globulin chain production, these Syndromes fall into $\alpha$-thalassemia and beta-thalassemia. (6) People whose hemoglobin does not produce enough alpha protein have alpha thalassemia, while people whose hemoglobin does not produce enough beta protein have beta thalassemia. (3) There are also rarer forms, ie $\gamma^{-}, \delta$ - and $\delta \beta$-thalassemia (6). If the body does not produce enough of both proteins, red blood cells will not form properly and will not be able to carry proper oxygen. Its result is anemia (6) which requires special medical treatment and requires these patients (for survival) regular blood transfusions and iron transporters (chelators) $(7,8)$. It is a monogenic disorder inherited from parents to children as an autosomal recessive disorder $(9,10)$ and is a non-communicable disease $(11,12)$. Its symptoms occur in the age of 10 to 12 months $(13,14)(1,15)$ and continues throughout life (3). Patients with thalassemia suffer from a variety of complications and symptoms, including severe and chronic anemia, stunted growth $(16,17)$, large spleen and liver, and bone disorders, especially visible changes in head and facial bones with a change in gaze $(11,18)$. Pale, yellow skin, decreased growth of gonads, protruding forehead are other symptoms (19). Thalassemia major is one of the most common chronic genetic diseases in the world and in Iran (11). There are approximately 300 million thalassemia patients worldwide each year $(20,21)$. Geographically, thalassemia is a Mediterranean disease and occurs in countries (Italy, Cyprus, Greece, Sicily), the Middle East (Iran, Turkey and Syria) (22, 23), northern India and parts of Southeast Asia (24) and North Africa (25, 26). Although accurate statistics on the prevalence of beta thalassemia in Iran are not available, but according to estimates, its prevalence in Iran is about $4 \%$, which is significantly higher than the global average prevalence of thalassemia $(1.5 \%)(27,28)$. Iran is among countries that are on the thalassemia belt in the world $(20,29)$ so that there are about 26,000 thalassemia patients $(20,30)$ and 2 to 3 million thalassemia carriers $(1,31)$. About 800 infants are born with thalassemia annually and added to this group $(30,32)$. The cities in which it is of the highest prevalence in Iran include marginal cities on the Caspian Sea, Persian Gulf, Mazandaran, Gilan, Khuzestan, Fars, Bushehr, Hormozgan, Sistan and Baluchestan and Kerman (11, 33). Thalassemia can have many adverse effects on the individual, family and society $(34,35)$. Psychologically, patients with thalassemia are under stress $(16,36)$. Eighty percent of patients with thalassemia major suffer from at least one mental disorder $(37,38)$. Patients with this chronic blood disorder may be in a state of anxiety, 
depression, and aggression because social problems such as thinking about the future, limited social activity, and limited access to school are among the factors that predispose to these disorders $(9,39)$. According to studies, depression in thalassemia patients also increases the risk of substance abuse and suicide $(1,40)$. Suicide is a multicausal and complex behavior that is caused by the interaction of various factors such as biological $(41,42)$, environmental and psychological ones (43, 44). Suicide and its attempt at the World Health Organization (WHO) session [1] in 1996, was declared as an important public health issue (45). It means harming oneself with the aim of destroying oneself $(46,47)$ as well as anger towards oneself $(41,48)$. The suicidal process falls into four main categories, which include thoughts, planning, action, and ultimately the completion of suicide (49). Suicidal ideation includes any thought of self-destruction (50). These thoughts contain a range of vague thoughts about the possibility of ending life to complete suicide $(51,52)$ but may never be fulfilled (53). In the planning stage of suicide, the person provides the appropriate conditions, tools or place for suicide. The attempt to commit suicide is a deliberate and conscious act, and is usually done to attract the attention of others. The purpose of this action is not to finish life (53). The fulfilled suicide, on the other hand, is, as defined by the World Health Organization, a conscious and deliberate attempt to kill oneself $(43,54)$. According to the statistics of World Health Organization (WHO), suicide is one of the leading causes of death worldwide (55). According to statistics released by the World Health Organization, it is estimated that every person commits suicide every 40 seconds (56). Between 800,000 and one million people die each year due to suicide (57) and twenty Millions attempt to commit suicide $(58,59)(60)$. The average prevalence of suicidal ideation, planning and fulfilling suicide in the world is $9.2,3.1$ and $2.7 \%$, respectively $(49,61)$. In Iran, the suicide rate, although lower than in Western countries, is higher than in other Middle Eastern countries (57). The prevalence of suicide attempts in Iran under the influence of cultural and regional factors varies from $16.8 \%$ of a thousand people in the south of the country to $117.8 \%$ of a thousand people in the north of the country $(53,62)$. Due to the existence of the phenomenon of suicide and suicidal ideation in all human societies from the past years until today, there have been studies in this field, which we make mention of some of them. Carballo et al. (2011) (63) conducted a study and found that adolescents with major depressive disorder were at risk for suicidal behaviors. The present study also showed that all adolescents in both thalassemia and comparison groups fall into the group with a history of suicidal ideation and depression. Through a semistructured interview (K-SADS), a study (64) examined the psychiatric diagnosis and suicide in children with thalassemia major. It predicted that suicidal ideation has a higher prevalence $(28.8 \%)$ than suicide intention $(5.1 \%)$ and suicide attempt (1.7\%). Moreover, it stated that children with thalassemia major were likely to be at risk for the clinical forms of depression and suicide; so providing routine screening for mental health problems as well as suicidal ideation can lead to early detection and treatment. Another study from Iran (65) reported $43.6 \%$ suicidal ideation, $27.3 \%$ suicidal intention and $7.3 \%$ suicide attempt in patients with thalassemia. However, the authors concluded that the suicide rate was similar to that of the general Iranian population, and that the diagnosis may not be associated with an increased risk of suicide. In another research, a relatively older group of Turkish patients with thalassemia (mean age: 17.42 \pm 4.65 ) reported in explanation a high level of suicidal ideation with a rate of $96.6 \%$ in patients and $98.4 \%$ in their caregivers (66). However, the literature on thalassemia and suicide is still very limited, and on the other hand, the results of the research background are not the same and do not have the necessary coherence. It is important to identify people who have the highest risk factors for suicide $(41,67)$. Early detection of suicidal ideation is also very important (49) because if we do not identify the person in whom suicidal ideation is formed and do not treated him, in the next stage he tries to plan for suicide (51). Therefore, it seems necessary to study the prevalence of suicidal ideation, and for this reason, we decided to study the prevalence of suicidal ideation in people with thalassemia.

\section{METHOD}

Research project and participants: The present study was descriptive cross-sectional. Its statistical population includes all thalassemia patients referred to Hazrat Ali Asghar (AS) Hospital in 2020. From among this statistical population, we selected 150 people through census by sampling at convenience. Criteria for inclusion were age range between 10 and 64 years, thalassemia, lack of comorbidity with other diseases. The criterion for exclusion was the patients' dissatisfaction and non-completion of the questionnaire.

Tool: Beck Questionnaire for Suicide Ideation: Beck and Steer (1991) prepared this questionnaire to reveal and measure the severity of attitudes and behaviors and to plan for committing suicide (68). This questionnaire is a nineteen-item self-assessment tool in which each scale is adjusted based on two point grades from 0 to 2 . A person's total score is calculated based on the sum of scores (0-38). There are five screening questions in Beck Suicide Ideation Test. If the answers indicate an active or passive suicidal tendency, the subject should also answer the next fourteen questions. The average time to complete the questionnaire is 10 minutes. On this scale, a score of $0-5$ indicates the absence of suicidal ideation, a score of 6-9 indicates suicidal ideation, and a score of 20-38 indicates intent to attempt suicide. Cronbach's alpha (internal consistency) and concurrent reliability of this scale were between 0.89 , 0.96 and 0.83 , respectively, and it is significantly associated with Beck Depression and Disappointment scales (68). This scale has been validated in Iran. Its reliability was 0.95 through Cronbach's alpha and its concurrent validity with the Depression Scale of the General Health Questionnaire was 0.76.

Procedure: After obtaining the necessary permits by referring to the research environment located in Hazrat Ali Asghar Hospital in Zahedan and providing a brief explanation about the purpose and process of this research, we provided the questionnaire to patients with thalassemia who expressed their satisfaction. They were also assured of the confidentiality of the information, and 
that the collected data would not be provided to any other body. At the end of data collection, we analyzed them by SPSS software. To obtain the results in descriptive statistics, we used frequency, mean, standard deviation, as well as independent t-test and analysis of variance.

\section{FINDINGS}

Gender distribution of the respondents in this research indicates that $57.3 \%$ of the respondents were male and $42.7 \%$ were female. As for marital status, 72 respondents were single and $28 \%$ were married. As for education, $6.7 \%$ of respondents were illiterate, $47.3 \%$ under diploma, $41.3 \%$ with diploma, $2 \%$ with high school degree, $1.3 \%$ were of BSc degree and $1.3 \%$ of them had MSc degree and above. In terms of the prevalence of suicide ideation and attempts, $78.7 \%$ of the respondents stated that they have suicidal thoughts, $14 \%$ were ready to commit suicide and $7.3 \%$ intended to commit suicide. As for the age, average age of the respondents was 23 years, minimum age 10 and the maximum age was 64 years (Table 1 ).

Table 1: Frequency of respondents by demographic variables

\begin{tabular}{|l|l|l|l|}
\hline Variables & Man & Frequency & Percentage \\
\hline \multirow{4}{*}{ Gender } & Woman & 64 & 57.3 \\
\hline \multirow{4}{*}{ Marital status } & Single & 108 & 42.7 \\
\cline { 2 - 4 } & Married & 42 & 72 \\
\hline Education & Illiterate & 10 & 28 \\
\cline { 2 - 4 } & $\begin{array}{l}\text { Under } \\
\text { diploma }\end{array}$ & 71 & 6.7 \\
\cline { 2 - 4 } & Diploma & 62 & 47.3 \\
\cline { 2 - 4 } & High school & 3 & 41.3 \\
\cline { 2 - 4 } & BSc & 2 & 2 \\
\cline { 2 - 4 } & MSc \& above & 2 & 1.3 \\
\hline \multirow{2}{*}{$\begin{array}{l}\text { prevalence of } \\
\text { suicide } \\
\text { attempts }\end{array}$} & $\begin{array}{l}\text { With suicidal } \\
\text { thoughts }\end{array}$ & 118 & 78.7 \\
\cline { 2 - 4 } & $\begin{array}{l}\text { Readiness to } \\
\text { suicide }\end{array}$ & 21 & 14 \\
\cline { 2 - 4 } & $\begin{array}{l}\text { Intention for } \\
\text { suicide }\end{array}$ & 11 & 7.3 \\
\cline { 2 - 4 } Age & Mean age & Minimum age & Maximum age \\
\cline { 2 - 4 } & 23 & 10 & 46 \\
\hline
\end{tabular}

According to Pearson correlation coefficient test, because the value of the significance level in the Pearson test table and the standardized covariance output is equal to 0.002 and 0.005 , and this value is less than the critical level and the standard error of 0.05 with a confidence of 0.95 , the above hypothesis is confirmable. The value of the correlation coefficient of these two variables is negative and equal to -0.23 . It indicates that these two variables have a relatively good correlation intensity. Due to the slope of the regression line in the dispersion diagram, it shows a negative and inverse relationship between the two variable. We can infer that there is a significant negative relationship between age and the prevalence of suicide thoughts and attempt, so that as the age increases, the prevalence of suicidal thoughts and attempts will decrease and vice versa (Table 2).

According to the results obtained from t-test of independent samples, since the significance level of prevalence of suicidal thoughts and attempt with a confidence of 0.95 is less than the error level of 0.05 , we can infer that the average prevalence of suicidal thoughts and attempt is of a significant difference between the two groups of men and women. Thus, the above hypothesis is confirmable. According to the above test, men have a higher average in the prevalence of suicidal thoughts and attempts than women and have an average difference of 1.10 higher than women (Table 3).

Table 2: Pearson correlation coefficient test in line with assessing the correlation between age and prevalence of suicidal thoughts and attempt. "It seems that there is a relationship between age and prevalence of suicidal thoughts and attempt"

\begin{tabular}{|l|l|l|l|}
\hline Pearson correlation coefficient test table \\
\hline Variable under study & Number & $\begin{array}{l}\text { Pearson } \\
\text { coefficient }\end{array}$ & $\begin{array}{l}\text { Significance } \\
\text { level }\end{array}$ \\
\hline Age & 150 & -0.234 & 0.002 \\
\hline $\begin{array}{l}\text { prevalence of suicidal } \\
\text { thoughts and attempt }\end{array}$ & 150 & & \\
\hline \multicolumn{3}{|l|}{ Standardized covariance output table } \\
\hline $\begin{array}{l}\text { Relationship } \\
\text { between emotional } \\
\text { intelligence and } \\
\text { entrepreneurship }\end{array}$ & $\begin{array}{l}\text { Standard } \\
\text { values }\end{array}$ & $\begin{array}{l}\text { Critical } \\
\text { points }\end{array}$ & $\begin{array}{l}\text { Significance } \\
\text { level }\end{array}$ \\
\cline { 2 - 4 } & 0.23 & 2.77 & 0.005 \\
\hline
\end{tabular}

Table 3: Independent samples t-test for evaluating and comparing the average prevalence of suicidal thoughts and attempt by gender variable

"It seems that the prevalence of suicidal thoughts and attempt is different between men and women."

Descriptive table of t-test for independent samples

\begin{tabular}{|l|l|l|l|l|}
\hline & Gender & Mean & $\begin{array}{l}\text { Standard } \\
\text { deviation }\end{array}$ & $\begin{array}{l}\text { Error of } \\
\text { Standard } \\
\text { deviation }\end{array}$ \\
\hline $\begin{array}{l}\text { prevalence } \\
\text { of suicidal } \\
\text { thoughts } \\
\text { and } \\
\text { attempt }\end{array}$ & Women & 0.79 & 2.43 & 0.26 \\
\cline { 2 - 5 } & Men & 1.89 & 3.67 & 0.47 \\
\hline Inference table of t-test for independent samples \\
\hline $\begin{array}{l}\text { Variable } \\
\text { under } \\
\text { study }\end{array}$ & t-test & $\begin{array}{l}\text { Significance } \\
\text { level }\end{array}$ & $\begin{array}{l}\text { Mean } \\
\text { difference }\end{array}$ & Test result \\
\hline $\begin{array}{l}\text { prevalence } \\
\text { of suicidal } \\
\text { thoughts } \\
\text { and } \\
\text { attempt }\end{array}$ & 2.17 & 0.04 & 1.10 & $\begin{array}{l}\text { Significant } \\
\text { difference }\end{array}$ \\
\hline
\end{tabular}

According to the results obtained from t-test of independent samples, since the significant level of prevalence of suicidal thoughts and attempt with a confidence of 0.95 is less than the error level of 0.05 , we can infer that the average prevalence of suicidal thoughts and attempt is not significantly different between the two groups of married and single people. Hence the rejection of the above hypothesis. According to the above test, married people have a higher average in the prevalence of suicidal thoughts and attempt than single people and have an average difference of 1.10 higher than single people. This difference is not a statistically significant difference (Table 4). 
Table 4: Independent samples t-test for evaluating and comparing the average prevalence of suicidal thoughts and attempt by marital status variable

"It seems that the prevalence of suicidal thoughts and attempt is different between two groups of married and single people."

Descriptive table of t-test for independent samples

\begin{tabular}{|l|l|l|l|l|}
\hline & Marriage & Mean & $\begin{array}{l}\text { Standard } \\
\text { deviation }\end{array}$ & $\begin{array}{l}\text { Error of } \\
\text { Standard } \\
\text { deviation }\end{array}$ \\
\hline $\begin{array}{l}\text { prevalence } \\
\text { of suicidal } \\
\text { thoughts } \\
\text { and } \\
\text { attempt }\end{array}$ & Married & 1.45 & 0.16 & 0.04 \\
\cline { 2 - 5 } & Single & 0.76 & 0.33 & 0.15 \\
\hline Inference table of t-test for independent samples \\
\hline $\begin{array}{l}\text { Variable } \\
\text { under } \\
\text { study }\end{array}$ & t-test & $\begin{array}{l}\text { Significance } \\
\text { level }\end{array}$ & $\begin{array}{l}\text { Mean } \\
\text { difference }\end{array}$ & Test result \\
\hline $\begin{array}{l}\text { prevalence } \\
\text { of suicidal } \\
\text { thoughts } \\
\text { and } \\
\text { attempt }\end{array}$ & 0.22 & 0.20 & 0.69 & $\begin{array}{l}\text { Significant } \\
\text { difference }\end{array}$ \\
\hline
\end{tabular}

According to the above test, since the significance level in the one-way analysis of variance (ANOVA) test for the prevalence of suicidal thoughts and attempt with a confidence of 0.95 is greater than the standard error level of 0.05 , we can infer that the mean prevalence of suicidal thoughts and attempt does not differ significantly according to different educational groups. Hence the rejection of the above hypothesis. Thus, the prevalence of suicidal thoughts and attempt does not differ between different educational groups. The highest to lowest acquired mean in the variable of prevalence of suicidal thoughts and attempt among different educational groups are 1. Higher school degree 2. Under diploma 3. Diploma 4. Illiterate 5. BSc degree 6. MSc degree and above (Table 5).

Table 5: One-way analysis of variance (ANOVA) test to evaluate and compare the average prevalence of suicidal thoughts and attempt according to different educational groups

"It seems that the prevalence of suicidal thoughts and attempt varies between different educational groups."

\begin{tabular}{|c|c|c|c|c|c|c|}
\hline \multicolumn{2}{|l|}{ Variable } & Mean & $\begin{array}{l}\text { Standard } \\
\text { deviation }\end{array}$ & $\begin{array}{l}\mathrm{F} \\
\text { value }\end{array}$ & $\begin{array}{l}\text { Significanc } \\
\text { e level }\end{array}$ & Test result \\
\hline \multirow{6}{*}{$\begin{array}{l}\text { prevalence } \\
\text { of suicidal } \\
\text { thoughts } \\
\text { and } \\
\text { attempt }\end{array}$} & Illiterate & $\begin{array}{l}1.2 \\
0\end{array}$ & 0.42 & \multirow{6}{*}{$\begin{array}{l}0.5 \\
5\end{array}$} & \multirow{6}{*}{0.73} & \multirow{6}{*}{$\begin{array}{l}\text { There is no } \\
\text { significant } \\
\text { difference } \\
\text { in the } \\
\text { prevalence } \\
\text { of suicidal } \\
\text { thoughts } \\
\text { and } \\
\text { attempt } \\
\text { between } \\
\text { different } \\
\text { educational } \\
\text { groups }\end{array}$} \\
\hline & $\begin{array}{l}\text { Under } \\
\text { diploma }\end{array}$ & $\begin{array}{l}1.3 \\
2 \\
\end{array}$ & 0.62 & & & \\
\hline & Diploma & $\begin{array}{l}1.2 \\
6\end{array}$ & 0.57 & & & \\
\hline & $\begin{array}{l}\text { High } \\
\text { school }\end{array}$ & $\begin{array}{l}1.6 \\
7\end{array}$ & 0.45 & & & \\
\hline & BSc & 1 & 0.10 & & & \\
\hline & $\begin{array}{l}\text { MSc \& } \\
\text { above }\end{array}$ & 1 & 0.14 & & & \\
\hline
\end{tabular}

\section{DISCUSSION}

Thalassemia major is one of the most common chronic genetic diseases in the world and in Iran (11). Thalassemia can have many adverse effects on the individual, family and society $(34,35)$. Psychologically, patients with thalassemia are under stress $(16,36)$. According to the World Health Organization (WHO), suicide is one of the leading causes of death worldwide (55). Identifying the people who have the highest risk factors for suicide is very important $(41,67)$. Early detection of suicidal ideation is very important (49) because if the person in whom the suicidal ideation is formed is not identified and not treated, he then tries to plan for suicide (51). Therefore, the present research investigates the frequency of thoughts, readiness and attempt for suicide in people with thalassemia. The first finding of this research was that there is a significant negative relationship between age and the prevalence of suicidal thoughts and attempt, so that as age increases, the prevalence of suicidal thoughts and attempt will decrease and vice versa. Due to the lack of direct research in this field, this finding is indirectly consistent with the studies of Shirali and Kokbi (49), Nock MK et al. (69) and Örengül AC et al. (64). It is inconsistent with the result of Yengil E et al. (66). In their study of prevalence and factors of suicide, Shirali and Kokabi concluded that the mean score of suicidal ideation in youth and adolescents was significantly higher than that in middle-aged and elderly people (49). In another international study, the results showed that the prevalence of suicidal ideation was inversely associated with age, so that the highest frequency of suicidal ideation was in the age group of 18-34, and with increasing age, the frequency of suicidal ideation decreases (69). Another research predicted that suicidal ideation was more common than suicidal intention and attempt. It also stated that children with thalassemia major might be at risk for subclinical forms of depression and suicide (64). According to these findings, in the present study, we observed that with increasing age, the prevalence of suicidal intention and attempt in people with thalassemia decreases. In the study of Yengil $E$ et al. (66), a relatively older group of Turkish patients with thalassemia reported high levels of suicidal ideation. The difference between the results of this study and our research can be due to the statistical population under study. Another finding of this research shows that the prevalence of suicidal intention and attempt is different between men and women. In this way, men have an average higher than that of women in terms of the prevalence of suicidal intention and attempt. Since no research has directly examined the prevalence of suicidal intention and attempt in patients with thalassemia, this finding is indirectly consistent with that of Heshmati et al. (46), Jan Bagheri and Bakhshi (70), Mousavi et al. (71). It is inconsistent with the results of Lee et al. (72), Sufi Afshar et al. (73), Shirali and Kokabi (49) and (74) Beautrais. According to the results of a research conducted by Heshmati et al., the prevalence of suicidal ideation was significantly higher in men than that in women (46). In two other studies conducted by Jan Bagheri, Bakhshi and Mousavi et al., suicidal ideation was more prevalent in men than women $(70,71)$. Although these researches have supported the higher prevalence of suicidal ideation in men than in women, we explain it by mentioning the role of men in making a living for themselves and their families. Men also are under a lot of psychological pressure, which can be one of the reasons for the increase in suicidal ideation in men; social, economic and cultural differences in this area are also relevant $(71,75)$. However, there is conflicting evidence; for example, in the study of Lee et al., the prevalence of suicidal ideation was higher in women than in men (72). In the study of Sufi Afshar et al., the prevalence 
of suicidal ideation was higher in women than in men (73). In addition, in a research done by Shirali and Kokabi, suicidal ideation was significantly associated with female gender, so that suicidal ideation was higher in women (49). In another study, Beautrais reported that in Western societies, the frequency of suicidal ideation and suicide attempt in women was twice as high as in men (74). Explaining the different results of the researches, we can state that the conditions of individuals in different studies may not have been homogeneous and the population of the present study, which is patients with thalassemia, was different from the population of other researches. Other reasons include differences in methods, intent, confidence, acceptability of the culture of suicide, psychological pathology (including substance abuse, mood disorders, external behaviors, and tendency to violence) and psychosocial differences between men and women (74). Another finding of this study was that married people had a higher average in the prevalence of suicidal ideation than single individuals, but this difference was not statistically significant. Indirectly, the results of Shirali and Kokabi indicate that suicidal ideation is far more common in divorced, single, and widowed individuals than in married individuals (49). Also in the study of Mohammadi Nia et al. we saw a higher rate of suicidal ideation of single students compared to married people (76). In contrast, in the study of Janqorbani some single people had less suicidal thoughts than married people (70). In explaining the cause of these differences, we can consider it to be caused by the influence of social, economic and cultural conditions. The latest finding of this research was that the acquired mean of the prevalence of suicidal thoughts and attempt did not differ significantly with respect to different educational groups. This result is indirectly consistent with the study of Sufi Afshar et al. and Heshmati et al. $(46,73)$. It contradicts the results of the study of Mohammadi Nia et al. and Fan et al. $(76,77)$. The results of the two mentioned studies showed that the prevalence of suicidal ideation was not significantly different between different educational levels $(46,73)$. While in the results of Mohammadi Nia et al., suicidal ideation is more prevalent in BSc degree than in high school degree (76). In a study, Fan et al. concluded that the rate of suicidal ideation increases with the upward trend of the school years (77). The difference between the results of these studies and our study can be due to the heterogeneity of the conditions of the subjects under study such as age, socio-economic status, support of others and the population under study. Finally, the findings of the present study are important in terms of the fact that so far there has been little continuous and reliable research on the prevalence of suicidal thoughts and attempt in patients with thalassemia. Many people still suffer from this blood disease and the family members and first-degree relatives are affected by it in the long run.

\section{CONCLUSION}

The findings of this research showed that among the patients with thalassemia, the prevalence of suicidal ideation has a significant percentage. Since suicidal ideation provides a platform for preparation and attempt to commit suicide, therefore, by providing mental health services and regular screening, we can take an effective step to prevent this problem among patients with thalassemia.

Limitations and Suggestions: One of the limitations of the present study is the small size of the research sample, which reduces its generalizability to all thalassemia patients. This is due to reduced literacy, inability to read and write, and unwillingness to participate in the research. Therefore, in future studies, we recommend a research with a larger sample size. The lack of a complete study of psychosocial indicators was another limitation of this study. Consequently, we suggest that in future researches, the researchers examine the impact of other variables such as social support and life expectancy and other demographic variables, including income levels. Finally, by the high incidence of thalassemia due to family marriages in Sistan and Baluchestan province, a similar research is necessary in the province.

Acknowledgments: This article is an excerpt from the Student Research Project approved by Zahedan University of Medical Sciences, with the ethical code IR.ZAUMS.REC.2021.096. We are very grateful to all the staff of Hazrat Ali Asghar Hospital in Zahedan who helped us in the implementation of this project.

\section{REFERENCES}

1. Nejad M. Elah, N. Mohammad A., Abdul Ghani, Yari A., Jassim, et al. Depression and its effective factors in patients with beta-thalassemia major referred to Saravan thalassemia center in 2019; 16 (2): 75-81.

2. Taher AT, Weatherall DJ, Cappellini MDJTL. Thalassaemia. 2018;391(10116):155-67.

3. Sacco M, Sciandra M, Maggio AJdSWPF. Random forest analysis: a new approach for classification of Beta Thalassemia. 2020.

4. Greer J, Arber D, Glader B, List A, Means RJP, PA. Wintrobe's clinical hematology, Lippincott Williams \& Wilkins. 2013.

5. Biswas B, Naskar NN, Basu K, Dasgupta A, Basu R, Paul BJJoE, et al. Care-Related Quality of Life of Caregivers of Beta-Thalassemia Major Children: An Epidemiological Study in Eastern India. 2020;10(2):168-77.

6. Rikos N, Giannadaki G-K, Spontidaki A, Tzagkaraki M Linardakis MJJoPH. Health status, anxiety, depression, and quality of life of patients with thalassemia. 2020:1-8.

7. Fard J., Fariborz, Solati, Kamal, Sharifi, Ghazanfari, et al. Effectiveness of mindfulness-based cognitive therapy on perceived stress, resilience and quality of life in patients with thalassemia major. 2019; 7 (4): 296-307.

8. Al-Harazi AA, Al-Eryani BM, Al-Sharafi BAJBrn. Neonatal hemolytic anemia does not always indicate thalassemia: a case report. 2017;10(1):1-5.

9. Saeed Manesh, Suhrawardi, Inability of JJ Mem. Effectiveness of positive parenting training on reducing anxiety and aggression in children with thalassemia. 2019; 9: $59-$

10. Mansilla-Soto J, Riviere I, Boulad F, Sadelain MJHgt. Cell and gene therapy for the beta-thalassemias: advances and prospects. 2016;27(4):295-304.

11. Mehr MA, Kalhorpour H, Shirani V, Seyed-Nezhad A, Kord A, Zainivand MJMS. Study of quality of life from the perspective of parents and children with thalassemia major. 2019;23(97):333-8.

12. Saberi SH, Alimehr M, Amiresmaili M, Seyednezhad MJEp Identifying the challenges of Iran's health houses and presenting a solution. 2016;8(10):3122.

13. hooshmandi R, Akabarian $\mathrm{s}$, bahreini $\mathrm{m}$, Mirzaei $\mathrm{K}$. The Relationship between Social Support and Depression in 
Patients with Thalassemia Major in Bushehr, Iran \%J nursing of the vulnerable journal. 2015;2(4):1-14.

14. Mevada ST, Al Saadoon M, Zachariah M, Al Rawas AH, Wali YJJopho. Impact of burden of thalassemia major on health-related quality of life in Omani children. 2016;38(5):384-8.

15. Hamed H, Ezzat O, Hifnawy TJMECP. Psychological manifestations in adolescents with thalassemia. 2011;18(4):237-44.

16. Mirqaed T., Massoud, Rad H., Farhadi, Sepehrian, Salemi, et al. Correlation between general health status of patients with thalassemia major and demographic characteristics. 2020; 9 (1): 18-24.

17. Alavi A, Parvin N, Kheyri S, Hamidizade S, Tahmasebi SJZMSUJ, Iran. Comparison attitude children with thalassaemia major and their parents about life quality of these children in Shahr-e Kord, Iran. 2007;8:35-41.

18. KHANI $H$, Majdi M, AZAD ME, MONTAZERI A, GHORBANI A, RAMEZANI M. Quality of life in Iranian Beta-thalassemia major patients of southern coastwise of the Caspian Sea. 2009.

19. Abu Shosha GM, Al-Kalaldeh M. The transactional model of stress and coping as guidance for understanding adolescent patients' experience with thalassemia: Case report. Journal of Child and Adolescent Psychiatric Nursing. 2020;33(1):4954.

20. Eri, Zuleikha, Hojjati, Hamid, Akhondzadeh, Bahar G. Effect of spiritual self-care training on self-efficacy of adolescents with thalassemia in Taleghani Gonbad Kavous Children's Hospital in 2017-18. Iranian Journal of Nursing Research. 2019; 14 (1): 8-13.

21. Al-Akhras A, Badr M, El-Safy U, Kohne E, Hassan T, Abdelrahman $\mathrm{H}$, et al. Impact of genotype on endocrinal complications in $\beta$-thalassemia patients. Biomedical reports. 2016;4(6):728-36.

22. Ahmadpanah $M$, Asadi $Y$, Haghighi $M$, Ghasemibasir $H$, Khanlarzadeh $\mathrm{E}$, Brand $\mathrm{S}$. In patients with minor betathalassemia, cognitive performance is related to length of education, but not to minor beta-thalassemia or hemoglobin levels. Iranian Journal of Psychiatry. 2019;14(1):47.

23. Babaei MR, Askarizadeh G, Towhidi A. The Effectiveness of Stress Management and Resilience Training (SMART) on Psychological Well-Being in Patients with Thalassemia Major. Preventive Care in Nursing \& Midwifery Journal. 2019;8(4):8-15.

24. Manne N, Gupta BK, Yadav SK, Singhal S, Dubey A. PREVALENCE OF HYPOTHYROIDISM, DELAYED PUBERTY AND DIABETES MELLITUS IN PATIENTS OF BTHALASSEMIA MAJOR. International Journal of Medical and Biomedical Studies. 2020;4(3).

25. Patel K, Bhivandkar S, Desai R, Antin T. The burden of psychiatric illnesses in adult patients with beta-thalassemia: a 5-year nationwide inpatient evaluation in the United States. Annals of hematology. 2019;98(4):851-60.

26. Galanello R, Origa R. Beta-thalassemia. Orphanet journal of rare diseases. 2010;5(1):11.

27. Shenas H. Predicting psychological distress based on cognitive emotion regulation and adaptive strategies in mothers of children with thalassemia. Quarterly Journal of Child Mental Health. 2019; 6 (3): 89-100.

28. Miri M, Tabrizi Namini M, Hadipour Dehshal M, Sadeghian Varnosfaderani F, Ahmadvand A, Yousefi Darestani S, et al. Thalassemia in Iran in last twenty years: the carrier rates and the births trend. Iranian Journal of Blood and Cancer . 7-11:(1)6;2013.

29. Behrouzian F, Khajehmougahi N. Relationship of coping mechanism of mothers with mental health of their major thalassemic children. Scientific Journal of Iran Blood Transfus Organ. 2014;10(4):387-93.
30. Khaledi S, Moridi G, Valiee S. Comparison the quality of life of healthy and Thalassemic children. 2013.

31. Behdani F, Badiee Z, Hebrani P, Moharreri F, Badiee $A H$ Hajivosugh $\mathrm{N}$, et al. Psychological aspects in children and adolescents with major thalassemia: A case-control study. Iranian journal of pediatrics. 2015;25(3).

32. Hojjati, Hamid, Qaisaran, Habib, Bakhshani, Noor Mohammad. Relationship between resilience and quality of life in parents with a child with thalassemia major in Zahedan. Journal of Rehabilitation Nursing Research. 2018; 5 (1): 36-43.

33. Hayatbakhsh M, Bahrampoor A. Stduy prevalence of minor thalassemia in in marriage volunteers in Kerman province. Journal of Shahid Sadoughi University of Medical Sciences. 2002;10:38-42.

34. Shamsaii, Parna, Akhondzadeh, Golbahar, Hojiati, Hamid. Effect of positive thinking training on parental adaptation of thalassemia adolescents. Journal of Nursing Education. 2019; 8 (1): 29-35.

35. Zinati F, Khashaninia Z, Rahgoi A, Rezasoltani $P$ Babamahmodi $F$. The effect of partnership caring model on quality of life of adolescents with major Thalassemia. Iranian Journal of Rehabilitation Research. 2016;2(2):57-67.

36. Khairkhah F, Mahmoodi Nesheli H, Khodabakhsh E, Hosseini SR. Evaluation of mental health and quality of life among $\beta$-thalassemia major patients. Caspian Journal of Pediatrics. 2015;1(2):54-9.

37. Mohammadzadeh E, Sarafraz M, Mohammadzadeh A, Ataei BNK. Prevalence of Depression Among Patients With Thalas-semia in Southern of Iran.

38. Hosseini SH, Khani $\mathrm{H}$, Khalilian A, Vahidshahi $\mathrm{K}$. Psychological aspects in young adults with BetaThalassemia major, control group. Journal of Mazandaran University of Medical Sciences. 2007;17(59):51-60.

39. Haji seyedJavadi A, Shafikhani A. Evaluation of depression and anxiety in patients with thalassemia: a comparative study. J Qazvin Univ Med Sci. 2017; 21 (2): 13-21. Archive of SID www SID ir.2.

40. Koutelekos J, Haliasos N. Depression and Thalassemia in children, adolescents and adults. Health Science Journal. 2013;7(3):239.

41. Aftab, Barmas, Hamed, Al-Husseini A. Predicting suicidal ideation based on five personality traits mediated by defense mechanisms. Clinical Psychology. 2019; 11 (3): 11-24.

42. Turecki G, Brent DA. Suicide and suicidal behaviour. The Lancet. 2016;387(10024):1227-39.

43. Miri, Shirazi, Mahmoud. Comparison of personality traits and suicidal ideation in two groups of suicide attempters with self-immolation and drug use. Clinical Psychology. 2017; 9 (1): 11-20.

44. Shakeri J, Farnia V, Abdoli N, Akrami MR, Arman F, Shakeri $\mathrm{H}$. The risk of repetition of attempted suicide among Iranian women with psychiatric disorders as quantified by the suicide behaviors questionnaire. Oman medical journal. 2015;30(3):173.

45. Salehi M, Beshlideh K, Kazemzade M. The Effect of Holographic Reprocessing Therapy on Impulsivity and Cognitive-Emotional Regoulation of Suicidal Persons in Ilam City. Ilam.

46. Heshmati, Khakpour, Sahel, Kowsari, Mohammadi, Zenozian. Prevalence of suicide in students of Zanjan University of Medical Sciences. Journal of Behavioral Science Research. 2019; 17 (1): 35-43.

47. Bakhtar M, Rezaeian M. The prevalence of suicide thoughts and attempted suicide plus their risk factors among Iranian students: a systematic review study. Journal of Rafsanjan University of Medical Sciences. 2017; 15 (11): 1061-76.

48. De Leo D, Krysinska K. Suicide and Self-Directed Violence. International Encyclopedia of Public Health: Academic Press; 2017. p. 115-23. 
49. Shirali, Ramin, Kokabi, Elias. Prevalence and factors related to suicidal ideation in the general population of Shiraz in 2017. Ilam University of Medical Sciences. 2019; 27 (3): 2736.

50. Babaei A., Golnaz, Atadokht, Mikaeli, Niloufar. Prevalence of suicidal ideation in female high school students in Naghadeh. 2019.

51. Pour Q., Elah A., Shafi'i, Rad H., Hadith. Investigating the relationship between cyber harassment and psychological vulnerability and suicidal ideation in male and female students. Quarterly Journal of Mental Health Research. 2017; 11 (3): 28-40.

52. Rostami C, Daliri S, Sayehmiri K, Delpisheh A, Sayehmiri F, Saadata M. The incidence of suicide attempt in Iran (200112): A meta-analysis. J Kermanshah Univ Med Sci 2016 2016;19(7):374-82.

53. Mohammadi D., Rezaian. Steps to Developing a Comprehensive Suicide Prevention Strategy: A Narrative Review. Scientific Journal of Rafsanjan University of Medical Sciences. 2020; 18 (11): 1155-82.

54. Kumar PS, Rajmohan V, Sushil K. An exploratory analysis of personality factors contributed to suicide attempts. Indian journal of psychological medicine. 2013; 35 (4): 378.

55. Fico G, Caivano V, Zinno $F$, Carfagno M, Steardo L, Sampogna G, et al. Affective temperaments and clinical course of bipolar disorder: an exploratory study of differences among patients with and without a history of violent suicide attempts. Medicine. 2019; 55 (7): 390.

56. Tack S. The logic of life: Thinking suicide through somatechnics. Australian Feminist Studies. 2019; 34 (99): 46-59.

57. Salehi, Mohammad Nabi, Hamid, Bashlideh, Arshadi. Comparison of the effectiveness of holographic reprocessing therapy and dialectical behavior therapy on cognitive flexibility and impulsivity of depressed patients attempting suicide in Ilam. Scientific Research Journal of Ilam University of Medical Sciences. 2019; 27 (5): 1-14.

58. Salehi, Mohammad Nabi, Hamid, Bashlideh, Arshadi. Comparison of the effectiveness of holographic reprocessing and dialectical behavior therapy on emotion control and social adjustment in depressed patients attempting suicide. Journal of Medical Science Studies. 2020; 30 (11): 924-40.

59. Perera $S$, Eisen $R$, Bawor $M$, Dennis $B$, de Souza $R$ Thabane $\mathrm{L}$, et al. Association between body mass index and suicidal behaviors: a systematic review protocol. Systematic reviews. 2015;4(1):52

60. Zamani N, Noohi S, Teimouri NN, Jahangir $\mathrm{AH}$ Effectiveness of Dialectical Behavior Therapy for Reducing Suicidal Thoughts (Suicidal Ideations) in Suicide Attempters with a History of Previous Suicide. Health Research. 2016;1(3):159-66.

61. Nock MK, Borges G, Bromet EJ, Alonso J, Angermeyer M, Beautrais $A$, et al. Cross-national prevalence and risk factors for suicidal ideation, plans and attempts. The British Journal of Psychiatry. 2008;192(2):98-105.

62. Khadem Rezaiyan M, Jarahi L, Moharreri F, Afshari R, Motamedalshariati S, Okhravi N, et al. Epidemiology of suicide attempts in Khorasan Razavi province, 2014-2015. Iranian journal of epidemiology. 2017;13(2):128-35.
63. Carballo JJ, Muñoz-Lorenzo L, Blasco-Fontecilla H, LopezCastroman J, García-Nieto R, Dervic K, et al. Continuity of depressive disorders from childhood and adolescence to adulthood: a naturalistic study in community mental health centers. The primary care companion to CNS disorders. 2011;13(5)

64. Örengül AC, Ucuz I, Oner Battaloglu N, Ozek G, Gormez V. Prevalence of psychiatric disorders and suicidality among children and adolescents with thalassemia major-A Turkish sample. Children's health care. 2019;48(1):120-9.

65. Ghanizadeh A, Khajavian S, Ashkani H. Prevalence of psychiatric disorders, depression, and suicidal behavior in child and adolescent with thalassemia major. Journal of pediatric hematology/oncology. 2006;28(12):781-4.

66. Yengil E, Acipayam C, Kokacya MH, Kurhan F, Oktay G, Ozer C. Anxiety, depression and quality of life in patients with beta thalassemia major and their caregivers. International journal of clinical and experimental medicine. 2014;7(8):2165.

67. Rogers ML, Ringer FB, Joiner TE. The association between suicidal ideation and lifetime suicide attempts is strongest at low levels of depression. Psychiatry research. 2018;270:3248.

68. Beck AT, Steer RA. Manual for the Beck scale for suicide ideation. San Antonio, TX: Psychological Corporation. $1991 ; 63$.

69. Nock MK, Hwang I, Sampson N, Kessler RC, Angermeyer $M$, Beautrais $A$, et al. Cross-national analysis of the associations among mental disorders and suicidal behavior: findings from the WHO World Mental Health Surveys. PLoS medicine. 2009;6(8):e1000123.

70. Janghorbani $M$, Bakhshi $\mathrm{S}$. The prevalence of suicide ideation and factors associated among students of Isfahan University of Medical Sciences, 2013-2014. Journal of Shahrekord Uuniversity of Medical Sciences. 2015;17.

71. SGh M. Relative frequency of suicidal ideation in students of Isfahan universities in 2005. 2008.

72. Lee H-S, Kim S, Choi I, Lee K-U. Prevalence and risk factors associated with suicide ideation and attempts in Korean college students. Psychiatry investigation. 2008;5(2):86

73. Soofi Afshar N, Bakhtar $M$, Aghamohammadhasani $P$ Rezaeian M. Suicidal Thoughts and Planning for Suicide among the 2007-2013 Entrance Medical Students of Rafsanjan University of Medical Sciences. Health and Development Journal. 2020;5(3):257-66.

74. Beautrais AL. Gender issues in youth suicidal behaviour. Emergency medicine. 2002;14(1):35-42.

75. Mirzaie SN, Shams Alizadeh N. Prevalence rate of suicida thoughts and its related factors in the medical students in Kurdistan University of Medical Sciences. Scientific Journal of Kurdistan University of Medical Sciences. 2013;18(1):1826.

76. Mohammadinia N, Rezaei M, Sameizadehtoosi T, Darban F. Assessing suicidal ideation frequency in medical students. Quarterly Journal of Nursing Management. 2012;1(1):83-91.

77. Fan AP, Kosik RO, Mandell GA, Tran DTP, Cheng HM, Chen $\mathrm{CH}$, et al. Suicidal ideation in medical students: who is at risk? Annals of the Academy of Medicine-Singapore. 2012;41(9):377 